\title{
Seasonal changes in the use of marine food resources by Cinclodes nigrofumosus (furnariidae, aves): carbon isotopes and osmoregulatory physiology
}

\author{
Cambios estacionales en el uso de recursos alimenticios marinos en Cinclodes \\ nigrofumosus (furnariidae, aves): isótopos de carbono y fisiología osmorregulatoria
}

\author{
PABLO SABAT ${ }^{1,2 *}$ \& CARLOS MARTÍNEZ DEL RÍO ${ }^{3}$
}

\author{
${ }^{1}$ Departamento de Ciencias Ecológicas, Facultad de Ciencias, Universidad de Chile, Casilla 653, Santiago 6513677, Chile; \\ ${ }^{2}$ Center for Advanced Studies in Ecology \& Biodiversity \\ ${ }^{3}$ Department of Zoology and Physiology, University of Wyoming, Laramie, Wyoming 82071, USA; \\ * e-mail for correspondenca: psabat@uchile.cl
}

\begin{abstract}
Passerines lack functional salt glands and to a large extent avoid feeding on marine invertebrates. An exception is Cinclodes nigrofumosus. Previous studies reported that the contents of its gastrointestinal tract had a lower osmolality than seawater suggesting that birds were supplementing their marine invertebrate diet with terrestrial invertebrates and fresh water at certain periods of the year. We report seasonal changes in the diet of $C$. nigrofumosus at two contrasting coastal localities in Central Chile and document the potential correlation between weather and feeding habits with osmoregulatory features in this species. We expected that C. nigrofumosus would increase its use of osmotically challenging marine dietary sources when fresh water is available. Animals were collected at El Quisco and Los Vilos from central Chile during the mist cool winter and during the hot and dry summer. Immediatly after capture several physiological and morphological variables were determined at the field. We used stable isotope analysis as a proxy variable to measure the relative contribution of marine and terrestrial sources to the diet of Cinclodes nigrofumosus. Our results support the notion that osmoregulatory factors constraint dietary selection: in both localities birds consumed more marine prey when environmental conditions were less stressing, i.e., when lower environment temperatures, higher humidity and more fresh water was available. Our results also indicate that osmoregulatory physiology does not respond in a similar fashion in both seasons and suggest that osmoregulatory physiology of birds is affected by environmental variables in a complex fashion.
\end{abstract}

Key words: Cinclodes, isotopes, renal function, osmoregulation, seasonal changes.

\section{RESUMEN}

Las aves paseriformes no poseen glándula de la sal funcional y en gran medida evitan el consumo de invertebrados marinos. Una excepción es Cinclodes nigrofumosus. Estudios previos han documentado que el contenido del tracto gastrointestinal posee una osmolalidad menor que el agua de mar, lo que sugiere que las aves complementan su dieta con presas terrestres y agua dulce, lo que solo ocurriría en ciertos períodos del año. Nuestro objetivo es documentar los cambios estacionales en la dieta de C. nigrofumosus en dos localidades costeras en Chile central y documentar la relación potencial entre el clima y los hábitos alimenticios y las características osmorregulatorias. Esperamos que C. nigrofumosus incremente la utilización de presas marinas cuando exista disponibilidad de fuentes de agua dulce. Los animales se colectaron en El Quisco y Los Vilos e inmediatamente después de su captura se determinaron variables fisiológicas y morfológicas en terreno. Nos basamos en el análisis de isótopos estables de carbono como medida de la contribución relativa de fuentes de carbono marinas y terrestres a la dieta de Cinclodes nigrofumosus. Los resultados del fraccionamiento isotópico apoyan nuestra hipótesis de restricción fisiológica sobre la selección de dieta: en ambas localidades las aves consumen mayor cantidad de presas marinas cuando las condiciones ambientales son menos estresantes, i.e., baja temperatura ambiental, alta humedad relativa y alta disponibilidad de agua dulce. Nuestros resultados indican que la fisiología osmorregulatoria no responde de manera similar en ambas estaciones y sugieren que la fisiología osmoregulatoria de las aves es afectada por las variables ambientales de una manera compleja.

Palabras clave: cambios estacionales, Cinclodes, función renal, isótopos, osmorregulación. 


\section{INTRODUCTION}

Because the tissues of marine invertebrates are in osmotic equilibrium with seawater, when sea birds ingest them, they also ingest a high load of salts (Sabat et al. 2003). Sea birds use salt glands to dispose of this osmotic load (Schmidt-Nielsen 1959). Passerines lack functional salt glands and to a large extent avoid feeding on marine invertebrates. Exceptions are several birds in the genus Cinclodes (Furnariidae). Sabat \& Martínez del Rio (2002) and Sabat et al. (2004a) documented differences in diet and osmoregulatory abilities among several species in this genus. Using gut content and stable isotope analyses, these authors found that one of these species, $C$. nigrofumosus, was very strongly dependent on marine invertebrates. Cinclodes nigrofumosus seem to be unusual not only in its reliance on a marine diet, but also in the mechanisms that it uses to dispose of salty diet. Briefly, the kidneys of $C$. nigrofumosus seem to have an unusually high capacity to concentrate urine. This species inhabits coastal sites that range relatively mesic in central Chile to hyperarid in northern Chile and southern Perú (Goodall et al. 1946, Hockey et al. 1987).

Animals can reduce the osmotic load imposed by a salty marine diet in two complementary ways: (1) by drinking fresh water, and (2) by having the ability to excrete high water loads. Sabat et al. (2003) studied a population of $C$. nigrofumosus at a costal mesic site and found that the contents of its gastrointestinal tract had a lower osmolality than seawater. This observation suggests two alternatives: either birds were supplementing their diet with terrestrial invertebrates and fresh water, or the lower osmolality of their gut contents reflected dilution of a marine diet with body fluid. The former possibility can only take place if birds have a source of fresh water and terrestrial invertebrates, something which may only occur at certain periods of the year in the markedly seasonal ecosystems of central Chile in which this species lives (Di Castri \& Hajek 1976).

The objective of this contribution is to report seasonal changes in the diet of $C$. nigrofumosus at two contrasting coastal localities in central Chile. We were also interested in documenting the potential correlation between weather and feeding habits with osmoregulatory features. In previous research we documented the usefulness of stable isotope analysis as a proxy variable that measures the relative contribution of marine and terrestrial sources to the diet of Cinclodes species (Sabat \& Martínez del Rio 2002 among other references). In general $\delta^{13} \mathrm{C}$, which measures the relative abundance of ${ }^{13} \mathrm{C}$ in samples, tends to be more positive in marine than in terrestrial food webs (Chisholm \& Nelson 1982, Griffiths 1991, Marra et al. 1998). The working hypothesis that informed our research was that $C$. nigrofumosus would increase its use of osmotically challenging marine dietary sources when fresh water is available. In Chile the wet season is the cold and rainy winter.

\section{MATERIAL AND METHODS}

Animals were collected with mist nets or shot between December to February (dry season) and from July to August (rainy season) at two sites: El Quisco (33⒊' S, 71 $\left.{ }^{\circ} 37^{\prime} \mathrm{W}\right)$ and Los Vilos $\left(31^{\circ} 54^{\prime} \mathrm{S}, 71^{\circ} 31^{\prime} \mathrm{W}\right)$ from 2000 to 2003. Los Vilos is a relatively xeric site (mean annual precipitation $162.2 \mathrm{~mm}$ ) whereas El Quisco is relatively mesic (mean annual precipitation $441.3 \mathrm{~mm}$, Di Castri \& Hajek 1976). Immediately after capture, a sample of ureteral urine was obtained by inserting a small closedended cannula into the birds' cloaca (Goldstein \& Braun 1989). Urine samples were centrifuged and the supernatant was saved for later analysis. After urine collection was completed, a blood sample (50 to $100 \mu \mathrm{L}$ ) was collected into heparinized tubes. Blood samples were centrifuged at $9,000 \mathrm{~g}$ for $5 \mathrm{~min}$, the hematocrit was recorded and the plasma was stored frozen $\left(-40^{\circ} \mathrm{C}\right)$ for no more than 1 week before osmometry analysis. Osmolality of the blood plasma and supernatant of urine were determined by vapor pressure osmometry (Wescor 5130B).

Birds were decapitated and their stomach (proventriculus and gizzard) contents were immediately removed and frozen in liquid nitrogen. Kidneys were removed, weighed and preserved in paraformaldehyde-glutaraldehyde. The area of medulla was estimated by point counting using the Cavalieri Principle on the 
right kidney, which was processed for routine light microscopy (Gundersen et al. 1988, Wauri 1989). Medullary cones were dissected from the left kidney using a dissecting microscope and the entire collection was counted. Gut contents were homogenized with a PotterElvehjem tissue grinder and centrifuged $(12,000 \mathrm{G}, 5 \mathrm{~min})$. The osmolality of the supernatant fluid was determined by vapor pressure osmometry (Wescor 5130B). Pectoralis muscle (ca. $0.15 \mathrm{mg}$ ) were freezedried, ground into a fine powder, and loaded into pre-cleaned tin capsules for isotopic analysis. Tissues were de-fatted by ether extraction prior to isotopic analyses. Carbon isotope ratios were measured on a continuous flow isotope ratio mass spectrometer (VG Isotech, Optima) with samples combusted in a Carlo Erba NA 1500 elemental analyzer at the Columbia University Biosphere 2 stable isotope facility. The precision of these analyses was \pm $0.3(\%)$ (SD). Lab standards, vacuum oil ( $\delta 13 \mathrm{C}$ $=-27.5 \% \circ$ VPDB $)$ and ANU sucrose $\left(\delta{ }^{13} \mathrm{C}=-\right.$ $10.5 \%$ VPDB, NAST 8542) were included with each run to correct raw values obtained from the mass spectrometer. Stable isotope ratios were expressed using standard delta notation $(\delta)$ in parts per thousand $(\% o)$ as:

$$
\delta^{13} \mathrm{C}=\left(\mathrm{R}_{\text {sample }} / \mathrm{R}_{\text {standard }}-1\right) \mathrm{X} 1000,
$$

where $R_{\text {sample }}$ and $R_{\text {standard }}$ are the molar ratios of ${ }^{13} \mathrm{C} /{ }^{12} \mathrm{C}$ of the sample and reference, respectively. Samples were referenced against international standard, VPDB.

\section{Statistical analysis}

To test for differences in morphological and physiological data, a two-way ANCOVA was performed, using body mass as the covariate when appropriate, and populations and season as fixed factors. Because we previously tested for differences among the sex of birds and no significant differences were fond in any traits, we removed this factor from the model. Aposteriori Tukey test multiple comparisons were performed to test for specific differences among means of physiological and morphological features. In addition, correlation analyses among isotopic signature, morphological, and osmoregulatory parameters were performed both separating data by season, locality and on pooled data. All statistical comparisons were conducted using Statistica for Windows (1997).

\section{RESULTS}

Diet isotopic composition: seasonal and habitat differences

The body mass of $C$. nigrofumosus did not differ between populations and seasons (Table 2). The pectoralis muscle was significantly more enriched in ${ }^{13} \mathrm{C}$ during the winter $\left(\delta^{13} \mathrm{C}=-12.63\right.$ $\pm 0.36)$ than during the summer $\left(\delta^{13} \mathrm{C}=-13.61 \pm\right.$ $0.53, \mathrm{~F}_{1,22}$ (season) $\left.=27.47, \mathrm{P}<0.001\right)$ but the magnitude of the effect of season on $\delta^{13} \mathrm{C}$ was the same at both sites $\left(\mathrm{F}_{1,22}(\mathrm{site})=0.001, \mathrm{P}=\right.$ $0.97, \mathrm{~F}_{1,22}$ (interaction) $=0.42, \mathrm{P}=0.52$ ) (Fig. 1). Kidney mass potentially covaries with body mass. Hence to examine the effect of site and season on this trait, we used analysis of covariance with body mass as a covariate. Body mass had a significant effect on kidney mass $\left(\mathrm{F}_{1,22}=9.6, \mathrm{P}=0.005\right)$, and when body mass is taken into account mass, kidney mass did not differ between seasons. However,we found a significant effect of locality and a significant interaction of season and site (Table 1) The number of medullary cones per gram kidney was unaffected by any factor (Table 2).

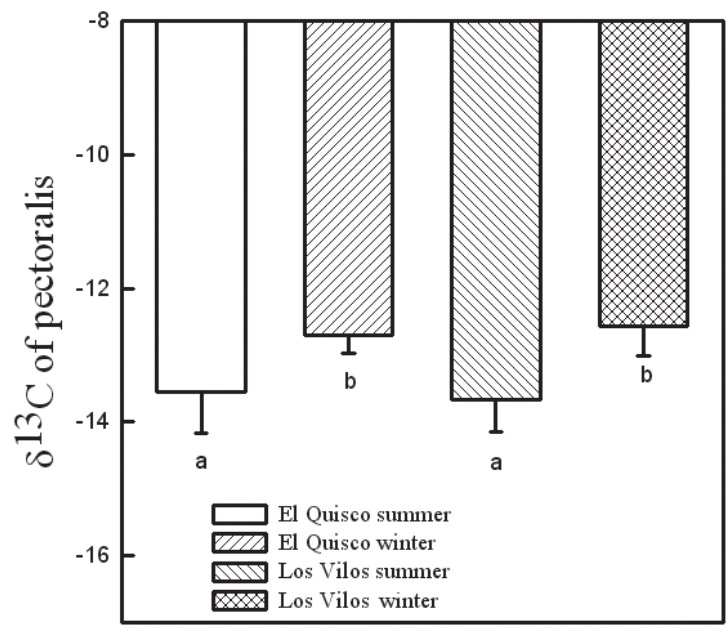

Fig. 1: Seasonal values of carbon isotopic composition of pectoralis of $C$. nigrofumosus in two localities from central Chile.

Valores estacionales de la composición isotópica de carbono del músculo pectoral de C. nigrofumosus en dos localidades de Chile central 
TABLE 1

Results of the ANCOVA for data on kidney mass of Cinclodes nigrofumosus in the field, using locality and season as factors and body mass as a covariate

Resultados del ANCOVA para datos del peso del riñón de Cinclodes nigrofumosus en terreno, usando localidad y estación como factores y peso corporal como covariable

\begin{tabular}{|c|c|c|c|c|}
\hline Factor & Mean square effect & Mean square error & $\mathrm{F}_{(1,22)}$-value & P-value \\
\hline Locality & 0.22508 & 0.01928 & 11.673 & 0.0024 \\
\hline Season & 0.00033 & 0.01928 & 0.017 & 0.8955 \\
\hline Interaction & 0.17359 & 0.01928 & 9.003 & 0.0065 \\
\hline
\end{tabular}

TABLE 2

Morphological measures and concentration of fluids (in $\mathrm{mOsm} \mathrm{kg}{ }^{-1}$ ) of Cinclodes nigrofumosus in the field. Summary of results of two-way ANOVA using locality and season as factors, are shown.

Different superscripts indicate significant differences among groups after a Tukey test; Cs = medullary cones by gram of kidney; data are presented as mean $\pm \mathrm{SD}$

Medias morfológicas y concentración de fluidos (en mOsm kg-1) de of Cinclodes nigrofumosus en terreno. Se muestra el resumen del resultado del ANOVA de dos vías utilizando la localidad y la estación como factores. Diferentes superíndices indican differencias significativas entre grupos después de la prueba de Tukey; $\mathrm{Cs}=$ conos medulares por gramo de riñón; los datos se presentan como promedio $\pm \mathrm{DE}$

\begin{tabular}{|c|c|c|c|c|c|c|c|c|c|c|}
\hline \multirow[t]{2}{*}{ Variable } & \multicolumn{2}{|c|}{ Los Vilos $(\mathrm{n}=15)$} & \multicolumn{2}{|c|}{ El Quisco $(\mathrm{n}=12)$} & \multicolumn{2}{|c|}{ Locality } & \multicolumn{2}{|c|}{ Season } & \multicolumn{2}{|c|}{ LxS } \\
\hline & Invierno & Verano & Invierno & Verano & $\mathrm{F}$ & $\mathrm{P}$ & $\mathrm{F}$ & $\mathrm{P}$ & $\mathrm{F}$ & $\mathrm{P}$ \\
\hline $\mathrm{Mb}(\mathrm{g})$ & $77.8 \pm 7.3$ & $74.5 \pm 7.9$ & $80.3 \pm 3.7$ & $78.8 \pm 3.4$ & 2.06 & 0.16 & 1.05 & 0.31 & 0.14 & 0.7 \\
\hline Kidney mass (g) & $1.31 \pm 0.15^{\mathrm{ab}}$ & $1.41 \pm 0.19^{b}$ & $1.31 \pm 0.15^{\mathrm{b}}$ & $1.12 \pm 0.13^{\mathrm{a}}$ & 5.02 & 0.03 & 0.38 & 0.54 & 5.43 & 0.02 \\
\hline Cs (n g-1) & $894.0 \pm 173.3$ & $735 \pm 196.2$ & $835.5 \pm 197.5$ & $748.6 \pm 145.5$ & 0.09 & 0.75 & 2.77 & 0.10 & 0.23 & 0.6 \\
\hline Plasma osmoality & $425.8 \pm 82.2^{\mathrm{a}, \mathrm{c}}$ & $399.4 \pm 65.4^{b, c}$ & $491.0 \pm 60.9^{\mathrm{a}}$ & $368.9 \pm 34.8^{b, c}$ & 2.39 & 0.13 & 15.26 & $<0.01$ & 7.89 & $<0.0$ \\
\hline Urine osmolality & $661.0 \pm 91.0^{\mathrm{d}}$ & $841.9 \pm 84.2^{\mathrm{a}}$ & $619.2 \pm 73.1^{\mathrm{b}, \mathrm{d}}$ & $623.9 \pm 94.5^{c, d}$ & 15.93 & $<0.01$ & 8.00 & $<0.01$ & 735 & 0.0 \\
\hline Diet osmolality & $836.7 \pm 84.9^{a, b}$ & $928.0 \pm 196.9^{\mathrm{a}}$ & $735.0 \pm 152.9^{b}$ & $688.6 \pm 130.3^{b}$ & 8.38 & $<0.01$ & 0.15 & 0.70 & 1.36 & 0.2 \\
\hline
\end{tabular}

The osmolality of the stomach differed only between sites. It was more concentrated at Los Vilos $(882.3 \pm 146.3)$ than at El Quisco $(711.8 \pm$ 137.2). Although some modification of fluids may occur because the food in the stomach is mixed with gastrointestinal secretions (Denbow 2000), decreasing its osmolality (Chang \& Rao 1994), this method provides a good estimator of the osmotic load in birds because (i) stomach content osmolality in Cinclodes species is positively correlated with urine osmolality in the field (Sabat \& Martínez del Rio 2002) and (ii) because stomach content osmolality and the osmolality of the preys consumed by marine and salt-marsh dwelling birds have very close values, if samples are collected just after feeding trials (Mahoney \& Jehl 1985, Janes 1997). Blood plasma osmolality was not influenced by collection site, but there was a significant interaction between site and season in this variable. Plasma osmolality was more concentrated in the cold rainy winter (455.6 \pm 72.4) than in the hot and dry summer $(385.2 \pm$ 137.17). This seasonal difference was more pronounced in the more southern region of El Quisco. Urine osmolality was affected both by the origin of birds and by the season. When pooled by locality the ANOVA revealed that the urine was more concentrated at El Quisco (621.3 \pm 81.8) than at Los Vilos $(764.3 \pm 122.5)$ whereas when data were pooled by season, the results indicates that the urine was more concentrated in summer $(739.8 \pm 141.9)$ than in winter $(640.1 \pm$ 77.0). When all data were considered (pooled), urine osmolality was positively correlated with both stomach content osmolality $(\mathrm{r}=0.46, \mathrm{P}=$ $0.02)$ and kidney mass $(r=0.58, P=0.002)$.

When all data were considered $\delta^{13} \mathrm{C}$ was only marginally correlated with the number of medullary cones per gram of kidney $(r=0.35$, 
$\mathrm{P}=0.09)$. When pooled by season, the osmolality of urine was positive correlated with the isotopic signature of pectoralis muscle $(\mathrm{r}=$ $0.81, \mathrm{P}=0.001)$ in winter. In summer, the osmolality of the urine was positive correlated with kidney mass $(\mathrm{r}=0.74, \mathrm{P}=0.003)$. Also, plasma osmolality was positive correlated with the osmolality of the diet $(\mathrm{r}=0.65, \mathrm{P}=0.002)$ and negatively correlated with the number of medullary cones per gram of kidney $(\mathrm{r}=-0.60$, $\mathrm{P}=0.03)$. In addition, urine and stomach content osmolality showed a positive but only marginal correlation $(\mathrm{r}=0.55, \mathrm{P}=0.06)$.

Because the variables measured were colinear, is difficult to ascertain whether the variation in their response was affected by season in a similar or different ways. To reduce the numer of correlated variables to smaller number, we performed a principal component analysis (PCA). We included all variables that showed any differences after analysis of variance, i.e., plasma, urine and stomach content osmolalities, the isotopic signature of pectoralis, and kidney mass (standardized by body mass). We additionally performed an ANOVA using the season as a factor and the PCA1 and PCA 2 as dependent variables. The results of this analysis revelaed that the five variables in the model were reduced to two PCA axes that accounted for about $65 \%$ of the variation (Table $3)$. The first component axis (PCA1) was strongly positively correlated with diet osmolality, urine osmolality and kidney mass, and weakly positively correlated with plasma osmolality and negatively correlated with $\delta^{13} \mathrm{C}$. The second axis (PCA2) was weakly correlated with diet osmolality, urine osmolality and kidney mass, but strongly and negatively correlated with $\delta^{13} \mathrm{C}$ and plasma osmolality (Table 3). Thus, we interpreted the PCA1 as an axis that measures kidney concentrative function (or antidiuretic condition), whereas the PCA2 can be interpreted as the intolerance of salt in the plasma (or the osmotic condition). A multivariate ANOVA revealed a strong effect of season of both axes (Wilk's lambda $=0.27, \mathrm{P}<$ $0.001)$. Concentrative function was higher when birds were exposed to low rain and humidity and higher temperatures in the summer. In a similar fashion, season had a very strong effect on PCA2 (Fig. 2). Birds captured in winter were exposed to higher osmotic loads than those captured in summer.

\section{TABLE 3}

PCA axes derived from analysis of osmoregulatory features in Cinclodes nigrofumosus in the field

Ejes del PCA derivados del análisis de características osmoregulatorias en 'Cinclodes nigrofumosus en terreno

\begin{tabular}{lcc}
\hline Factor loadings & PCA axis 1 & PCA axis 2 \\
\hline Plasma osmolality & 0.10 & -0.81 \\
Diet osmolality & 0.73 & -0.15 \\
Urine osmolality & 0.91 & -0.09 \\
$\delta^{13}$ C muscle & -0.25 & -0.76 \\
Kidney mass & 0.74 & -0.10 \\
Variance explained $(\%)$ & 39.73 & 25.41 \\
Cumulative variance explained $(\%)$ & 39.73 & 65.05 \\
\hline
\end{tabular}

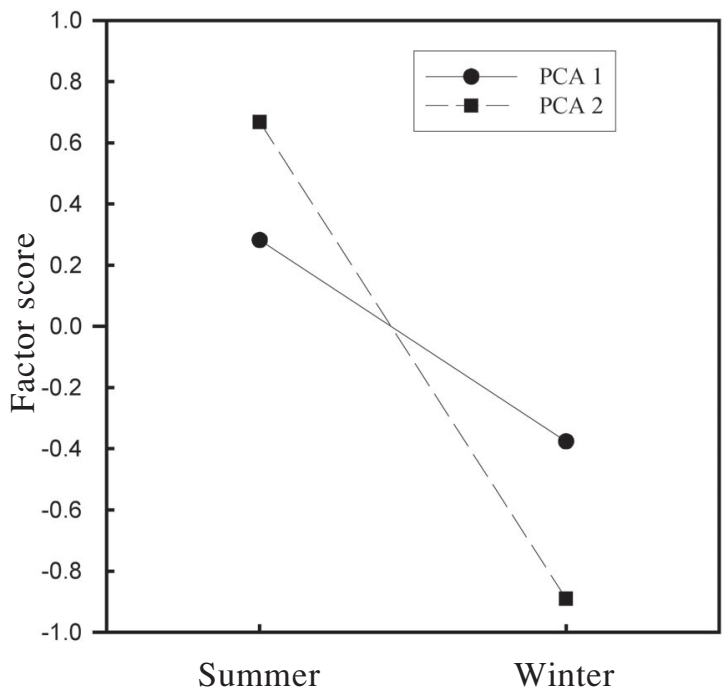

Fig. 2: Results of the principal component analysis (PCA) including the folowing variables in the model: plasma, urine and stomach content osmolalities, the isotopic signature of pectoralis, and kidney mass of $C$. nigrofumosus. PCA 1 axis may be interpreted as antidiuretic condition whereas PCA 2 as the osmotic condition. Both axis are strongly affected by season (see text for details).

Resultado del análisis de componentes principales incluyendo las siguientes variables en el modelo: osmolalidad de la orina y del contenido estomacal, enriquecimiento isotópico del músculo pectoral y la masa del riñón de $C$. nigrofumosus. El eje PCA 1 puede ser interpretado como la condición antidiurética mientras que el eje PCA 2 como la condición osmótica. Ambos ejes son afectados fuertemente por la estación (véase el texto para detalles). 


\section{DISCUSSION}

The diet of $C$. nigrofumosus individuals collected in winter was enriched in $\delta^{13} \mathrm{C}$ relative to the diet of individuals collected in summer. At both localities birds consumed more marine prey when ambient temperatures are lower, atmospheric humidity is higher and there is more fresh water available from temporary ponds produced by rain or from dew formed in the vegetation (see Sabat et al. 2003). Higher ambient temperatures increase the total evaporative water loss and hence may allows reduce the extent to which $C$. nigrofumosus rely on marine prey (Tielemann et al. 1999, Tielemann et al. 2002a, 2002b). An increase in water loss by evaporation, without fresh water to drink probably decreased the net amount of water to excrete the electrolyte load imposed by the consumption of salt-loaded marine invertebrates. Total evaporative water loss may be in fact a critical physiological variable that constrains dietary niche breadth.

Sabat et al. (2004c) demonstrated that $C$. nigrofumosus had reduced mass specific evaporative water losses at $25{ }^{\circ} \mathrm{C}$ than its congeners $C$. oustaleti and $C$. fuscus. This observation suggests that this variable may explain in part the observed differences in dietary selection at interspecific level. Cinclodes fuscus and $C$. oustaleti consume significant more terrestrial preys than $C$. nigrofumosus (Sabat \& Martinez del Rio 2002, Sabat \& González 2003). The same principle may apply to lower ambient humidity; which increases the total evaporative water loss (Tielemann et al. 1999, Williams \& Tielemann 2001). As mentioned, the higher precipitation observed in winter may allow $C$. nigrofumosus to processing the increased electrolyte load imposed by higher consumption of marine prey. Although we expected differences in the consumption of marine prey between sites, we found no difference in the $\delta^{13} \mathrm{C}$ of pectoralis between sites. The climatic differences between these two sites may not be sufficient to have an effect. Although the mean anual precipitation is significantly higher in El Quisco than in Los Vilos, the mean temperature of Los Vilos in summer $\left(18-19^{\circ} \mathrm{C}\right)$ and winter $\left(10-11^{\circ} \mathrm{C}\right)$ is only lightly higher than mean temperature of El Quisco $\left(16-15^{\circ} \mathrm{C}\right.$ and $9-8{ }^{\circ} \mathrm{C}$ for summer and winter respectively, see Di Catri \& Hajek (1976) and www.worldclimate.com).
Future research that incorporates a more pronounced geographic gradient in temperature and precipitation may be useful to give a clearer picture on the effect of climate on the dietary niche breath of Cinclodes.

\section{Physiological effects}

In spite of the similitude of isotopic signature of birds between localities, we observed several differences in physiological parameters. The stomach contents of birds at Los Vilos had higher osmolalities than those of birds at El Quisco and the birds at Los Vilos also had heavier kidneys than those at El Quisco. This result is in agreement with a previous report (Sabat \&Martínez del Rio 2002). In that study we hypothesized that these intraspecific differences might be the result of population differentiation or the result of phenotypic plasticity, i.e. of the acclimatization of individuals to varying fresh water availability and higher evaporative water losses. The significant seasonal changes in kidney mass at El Quisco coupled with the similar kidney mass between birds from both localities in winter, support the second hypothesis, i.e., the presence of phenotypic plasticity in kidney structure. Also, in a recent study on three species of Cinclodes, Sabat et al. (2004a) reported the ability of birds to change the morphology and size of kidney in laboratory acclimation experiments. Because the number of medullary cones remains unchanged, the change is only in kidney mass. Goldstein \& Ellis (1991) found that, in dehydrated adult quail, the mass of medullary tissue (but not kidney mass) was enhanced, and this increase did not involve an increased number of medullary cones.

The results of principal components are seemingly counterintuitive. In the summer, birds cannot dilute stomach contents with fresh water and their kidneys must increase their concentrative ability. In winter, osmotic condition (plasma osmolality) seems to be affected by the higher salt content of marine prey (Fig. 2). The elevated plasma osmolalities birds captured in winter (compared with summer birds) also seems consistent with the suggestion of high solute intake due to the incorporation of a great proportion of marine preys. However, the opposite trend is observed in urine osmolality, which is higher in summer birds. The same trend 
is observed in plasma osmolality that suggest a functional relationship between both variables. In fact these variables are positive correlated when all individuals are included in the analysis. Our results indicate that osmoregulatory physiology does not respond in a similar way in both seasons. Several studies have shown that the kidney function is coupled with plasma osmolality, which in turn may be modulated by the ingestion of solutes and the availability of water (Poulson and Bartholomew 1962, Goldstein et al. 1990). Our results suggest that osmoregulatory physiology of birds is affected by environmental variables in a complex fashion.

Casotti (2001) have documented that the relative mass of the kidney and the proportion of medullary tissue in house sparrows did not differ with habitat or season, in spite of marked differences in relative humidity and fresh water availability. Our results indicate that the consumption of marine salty prey has a stronger effect on plasma osmolality than the availability of water. Plasma osmolality was more concentrated in the rainy season, when birds consumed more marine prey. However plasma osmolality was affected by the osmolality of diet only in summer when fresh water is scarce. In winter (see Fig. 3) when birds can consume fresh water, there is no correlation between the omolality of food and that of plasma (Sabat et al. 2003). Fresh water availability may be the main factor that modulates the ability of Cinclodes to consume highly saline marine preys. However, further studies are needed to identify the multiple environmental factors that are important for osmoregulation in birds and how they interact, to understanding the functional relationships between physiological capacities that could constraint dietary breath in birds.

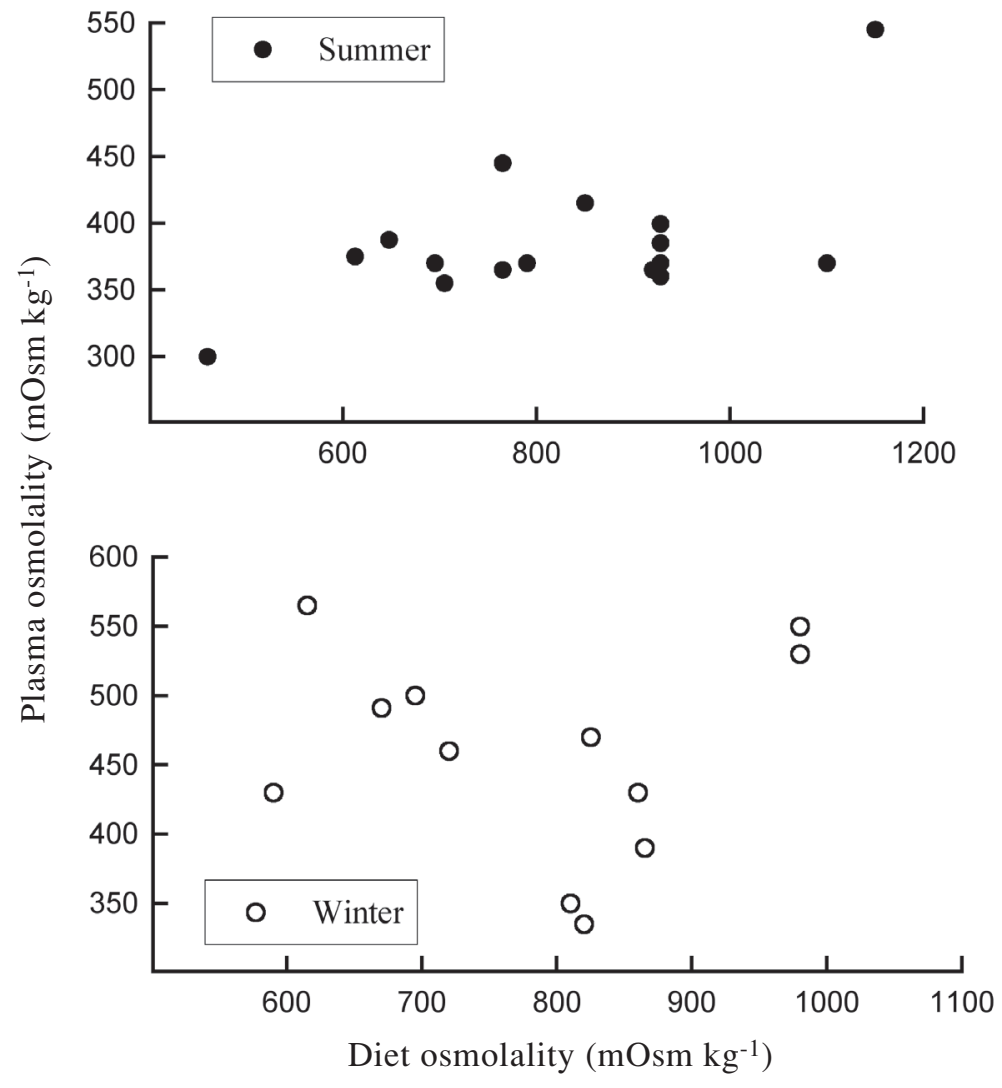

Fig. 3: Plama osmolality of $C$. nigrofumosus as a function os osmotic load (stomach content osmolality) in summer and winter. Note that the possitive and significant relationship between variables present in the dry season (summer), disappear in the rain season (winter).

Osmolalidad del plasma de C. nigrofumosus en función de la carga osmótica (osmolalidad del contenido estomacal) en verano e invierno. Nótese que la relación positiva y significativa presente en la estación seca (verano) desaparece en la estación lluviosa (invierno). 


\section{ACKNOWLEDGEMENTS}

This study was funded by FONDECYT grant № 1010647 to PS. Mauricio Canals criticized previous drafts of the manuscript Karin Maldonado provided invaluable assistance on histological analysis and procedures, and Andres Sazo provided field assistance. All the experiments comply with the current laws of Chile, where the experiments were performed. This paper is dedicated to the memory of our friend Mario Rosenmann.

\section{LITERATURE CITED}

CASOTTI G (2001) Effects of season on kidney morphology in house sparrows Journal of Experimental Biology 204: 1201-1206.

CHISHOLM BS \& DE NELSON (1982) Stable-carbon isotope ratios as a measure of marine versus terrestrial protein in ancient diets. Science 216: 1131-1132.

DI CASTRI F \& ER HAJEK (1976) Bioclimatología de Chile. Ediciones Universidad Católica de Chile, Santiago, Chile. 129 pp.

GRIFFITHS H (1991) Applications of stable isotope technology in physiological ecology. Functional Ecology 5: 254-269.

GOLDSTEIN DL \& CC ELLIS (1991) Effect of water restriction during grouth and adulthood on kidney morphology of bobwhite quail. American Journal of Physiology 261: R117-R125.

GOLDSTEIN DL \& EJ BRAUN (1989) Structure and concentrating ability in the avian kidney. American Journal of Physiology 25: R501-R509.

GOLDSTEIN DL, JB WILLIAMS \& EJ BRAUN (1990) Osmoregulation in the field by salt-marsh Savannah sparrows Passerculus sandwichensis beldingi. Physiological Zoology 63: 669-682.

GOODALL J, AW JOHNSON \& RA PHILIPPI (1946) Las aves de Chile. Volumen 1. Platt Establecimientos Gráficos, Buenos Aires, Argentina. 439 pp.

GUNDERSEN HJ, GL BENDTSEN, N KORBO, A MARCUSSEN, K MOLLER, JR NIELSEN, B NYENGAARD, FB PAKKENBERG, FB SORENSEN, A VESTERBY \& MJ WEST (1988) Some new, simple and efficient stereological methods and their use in pathological research and diagnosis. Acta Pathologica Microbiologica et Immunologica Scandinavica 96: 379-394.

HOCKEY PAR, AL BOSMAN \& PG RYAN (1987) The maintenance of polymorphism and cryptic mimesis in the limpet Scurria variabilis by two species of Cinclodes (Aves: Furnaridae) in central Chile. The Veliger 30: 5-10.

JANES DN (1997) Osmoregulation by Adelie pinguin chicks on the Antarctica peninsula. Auk 114: 488495.
MAHONEY SA \& JR JHEL Jr (1985) Physiological ecology and salt loading of California gulls at an alkaline, hypersaline lake. Physiological Zoology 58: 553-563.

MARRA PP, KA HOBSON \& R HOLMES (1998) Linking winter and summer events in a migratory bird by using stable-carbon isotopes. Science 282: 18841886.

POULSON TL \& GA BARTHOLOMEW (1962) Salt balance in the savannah sparrow. Physiological Zoology 35: 109-119.

SABAT, P \& S GONZÁLEZ (2003) Digestive enzymes in two species of marine 'Cinclodes (Passeriformes: Furnariidae). Condor 105: 830-833.

SABAT P, JM FARIÑA, M SOTO-GAMBOA (2003) Terrestrial birds living on marine environments: does dietary composition of Cinclodes nigrofumosus (Passeriformes: Furnariidae) predict their osmotic load? Revista Chilena de Historia Natural 76: 335-343

SABAT, P \& C MARTÍNEZ DEL RÍO (2002) Inter- and intraspecific variation in the use of marine food resources by three Cinclodes (Furnariidae, Aves) species: carbon isotopes and osmoregulatory physiology. Zoology 105: 247-256.

SABAT P, K MALDONADO, A RIVERA-HUTINEL \& G FARFAN (2004a) Coping with salt without salt glands: osmoregulatory plasticity in three species of coastal songbirds of genus Cinclodes (Passeriformes: Furnariidae). Journal of Comparative Physiology B 174: 415-420.

SABAT P, E SEPÚLVEDA-KATTAN \& K MALDONADO (2004b) Physiological and biochemical responses to dietary protein in the omnivore passerine Zonotrichia capensis (Emberizidae) Comparative Biochemistry and Physiology A 137: 391-396.

SABAT P, R NESPOLO \& F BOZINOVIC (2004c) Water economy of Cinclodes (Furnariidae) inhabiting marine and freshwater ecosystems. Revista Chilena de Historia Natural 77: 219-225.

STATISTICA (1997) STATISTICA (Quick Reference) for the Windows 95 operating system. StatSoft, Inc., Tulsa, Oklahoma, USA.

TIELEMAN BR, JB WILLIAMS, G MICHAELI \& B PINSHOW (1999) The role of the nasal passages in the water economy of crested larks and desert larks. Physiological and Biochemical Zoology 72: 219226.

TIELEMAN BR, JB WILLIAMS \& P BLOOMER (2002a) Adaptation of metabolism and evaporative water loss along an aridity gradient. Proceedings of the Royal Society of London 270: 207-214.

TIELEMAN BI, JB WILLIAMS \& MB BUSCHUR (2002b) Physiological adjustments to arid and mesic environments in larks (Alaudidae) Physiological and Biochemical Zoology 75: 305313

WAURI, CN (1989) Ligth microscopic morphometry of the kidneys of fourteen avian species. Jounal of Anatomy 162: 19-31.

WILLIAMS JB \& BI TIELEMAN (2001) Physiological ecology and behavior of desert birds. Current Ornithology 16: 299-353. 